\title{
Learning History by Qualified Teacher Education beyond History
}

\author{
Apdelmi \\ Jambi University \\ Jambi, Indonesia \\ apdelmi1985@gmail.com
}

\begin{abstract}
This study aims to investigate the implementation of learning history by a qualified teacher education outside of history. This research was conducted in SMA Saraswati 1 Denpasar. This type of the research is qualitative descriptive, as in this study presents the findings in the form of a detailed description, complete, and depth that describes the actual situation of the state. The strategy used in this study is a single case study. The data source consist of (1) The informant is a history teacher qualifications beyond history education, peer teachers, principals, and students, (2) activities of a history lesson on Saraswati 1 high school, Denpasar. (3) The documents and archives that diploma teachers and the teaching of history. Data collection techniques used are direct observation, interviews and document analysis. To obtain the validity of the data is done by triangulation of sources, theory, research, and methods. Data analysis technique using an interactive technique that consists of data collection, data reduction, data presentation, and conclusion. The results obtained show that the implementation of the teaching of history in high school Saraswati 1 Denpasar, when seen from the preparation, implementation, methods, media, until the evaluation, can be said that the educational qualifications of teachers outside of history better than a qualified teacher of history education
\end{abstract}

Keywords - History education; learning history; teacher

\section{INTRODUCTION}

Education is a process of instilling and developing in students the knowledge of life, the attitude in life so that later he can distinguish the right and wrong, good and bad so that his presence in the middle of society will be meaningful and functioning optimally [1]. National education has the goal to educate the life of the nation and develop a complete Indonesian man, the man who believes in God Almighty.

School is an educational institution that has a duty to deliver students to develop all the potential they have. Schools are also believed to be the only way that today's humans can live well in the future. The success of education in schools is very dependent on the process of teaching and learning in the classroom.

Talking about the teaching and learning process will not be separated from the talk of teachers because, in the whole system of education and learning, the role of teachers is very strategic. Teachers' duties relate to the development of human resources that will ultimately determine the sustainability and glory of the nation's life. In the context of the teaching and learning process in the classroom, the role of the teacher cannot be replaced by any modern electronic tools.
Declining education one of them caused by teachers who are not professional in carrying out his profession as a teacher so that students are less interested in following the learning. One of them on the subject of history. Competent teachers will be better able to create an effective environment and will be able to manage the class well so that the learning objectives will be achieved.

The teachers' lack of professionalism is due to the fact that teachers are teaching in a field that is not their expertise. Therefore, this study was conducted to determine the implementation of learning history by teachers who qualified outside of history education.

\section{METHODS}

This type of research is qualitative descriptive because in this study presents findings in the form of detailed description, complete, and depth describing the situation of the actual situation. The strategy used in this study is a single case study. Source of data consist of (1) Informant that is history teacher outside qualification of history education, peer teacher, principal, and student, (2) Event or activity of learning history implementation at SMA Saraswati 1 Denpasar. (3) Documents and archives are teacher certificates and historical learning tools. Data collection techniques used are direct observation, interviews, and document analysis. To obtain the validity of data is done by triangulation of sources, theories, researchers, and methods. While the technique of data analysis using interactive techniques consisting of data collection, data reduction, data presentation, and drawing conclusions.

\section{RESULT AND DISCUSSION}

\section{A. Implementation of History Learning}

Good learning takes place through a process, in which the process contains the activities of teachers in preparing the preparation of various learning decisions that will be implemented in the learning activities in the classroom to achieve the goals set. The purpose as stated in the KTSP is in the form of mastery of certain basic competencies by learners so that students have certain competencies in accordance with the objectives of learning and standards of competence established so that it can be said that learning planning refers to the objectives to be achieved previously set.

Planning to learn as a preparation stage and is the first step in learning has a very important role before the learning begins in the classroom. Well-planned and well-planned planning of 
learning will be very influential indeed on the quality of the learning process is implemented and the expected results will be achieved optimally. The better the plan made by the teacher the better the learning activities will be implemented in the classroom and vice versa. Thus a teacher must be prosecuted to be able to make well plan program and correctly and able to balance the material to be delivered correctly so as to be able to produce a good learning process.

Based on an interview with a history teacher with an archeology background, Leci said that before entering the class I prepare various purposes that will be used in the teaching and learning process, because as a good teacher I try to prepare myself well before teaching like I prepare the syllabus at the beginning of the semester and prepare for the year and semester program and make the RPP well. To prepare all of that I was guided by the results of the teachers of the subject of history (MGMP), but I do not imitate everything from the results of the subject teachers meeting alone. In making the learning tool I try to find materials or sources that are relevant or in accordance with the material that I will teach. Furthermore, in making RPP the taught material must be properly selected properly and correctly in accordance with the needs of students. It is not easy for me to make a good learning tool, but I have to be able to do it all by itself although for learning resources like books and others I also work with other teachers friends. The making of my RPP makes itself guided by the MGMP because at the beginning of the year I have to submit the RRP to the principal before I enter the class. I am guided by MGMP in that I do not model everything from RPP created by MGMP, but I use ATM terminology: capture, copy and modify. Apart from that I must know or have a goal to be achieved in the process of teaching and learning in order to achieve the goal of education to be achieved. With the learning tools such as syllabus, annual program, semester program, and learning implementation plan (RPP) so that the implementation of teaching and learning process can run well in the sense can be implemented in structured and can carry out the teaching and learning process in accordance with predefined competency standards. The goal is none other than to create a good learning style in order to achieve the learning objectives to be achieved.

In the implementation of learning in the classroom teachers play a very important role to determine the success of students in learning. Therefore, the teacher must really have expertise in accordance with their respective fields, so that the teacher is able to carry out the duties. In the implementation of teaching and learning process teachers should be a good example for students. A teacher must prepare maximally all the learning devices needed before entering the class so that the achievement of educational goals as expected. When teachers enter the classroom teachers are required to be able to manage the class well,? so that the learning process can run optimally. Teachers are also required to be able to generate or motivate students to learn so that students can actively ask questions about the material being taught. Thus the teaching and learning atmosphere becomes lively and fun for the students.

Based on the results of observation on the implementation of learning in the classroom, can be seen there are some components that can be seen related to the implementation of learning that is, a) learning materials, b) learning methods, c) learning media and d) evaluation.

\section{1) Learning materials}

Mastery of learning materials is very important, because if a teacher does not master the material taught well then the learning objectives will not be achieved as expected. This will affect the pursuit of classroom pursuits, students will look bored, saturated, feel not interested in learning history because the teacher does not master the material well. Usually, teachers who do not master the material with both teachers will be autocratic to cover the deficiencies, so the process of teaching and learning will not live.

Historical learning material in high school (SMA) is an independent subject and a group of general subjects. Historical subjects are given in all programs both in natural science (IPA) and in social science programs (IPS). However, in terms of time allocation is given differently between science programs (IPA) between social sciences (IPS). In general, social science programs get more hours of history education lessons than the science majors (IPA). In the social science department, they get three hours of lessons a week, while their natural science (IPA) course only gets one lesson a week with 45 minutes time allocation.

In conveying learning materials, teachers have difficulties in terms of allocation of time given for an inadequate history lesson. However, the material that must be delivered to the students is very broad while the time is very little so that the goal to be achieved not in accordance with expectations. To anticipate that teachers try to be able to deliver all the material on the students, teachers give the task to the students to read in the home material to be taught next week.

Based on interviews with history teachers with educational background from historical education Sukarta said: in the implementation of classroom teaching I only stick to the packaged book (Platinum) and I use the student worksheet (LKS). Every student is required to have student worksheet (LKS), so after I explain my chase material give an assignment to the student to do student worksheet (LKS). This I do to make it easier for teaching and students do not go out to class during study hours. I only use one package book (Platinum) and student worksheet (LKS) only.

Do you not seek to find books or other sources related to the material you are teaching?

In fact? exist, but with the condition of students let alone use a variety of sources one book package and student worksheet just is not easy to apply it let alone have to find other sources related to learning materials.

Do you teach in the class according to the implementation plan (RPP) that you have made?

I do not teach according to what is written in the lesson plan (RPP). The lesson plan (RPP) is only a formality as well as the learning plan (RPP) instead of me making it, all made by the Teachers Consultative Teams (MGMP) team. So in the implementation of teaching and learning process if I find new difficulties? see learning implementation plan (RPP). 
Furthermore, the results of interviews with teachers with educational background from Madar history education said: in the implementation of learning in the classroom I teach in accordance with what is written in the draft of the implementation of learning (RPP), but sometimes misses due to the condition of the students. For example, in the lesson plan (RPP) the method I use is the method of discussion, but when I get to class the students are not ready for discussion yet. To overcome this I took the initiative myself to change the learning method at the meeting.

\section{Do you make any lesson plan (RPP) for each meeting?}

No, the learning implementation plan (RPP) is made only once a semester. The learning implementation plan (RPP) is made by the subject teachers consultative team (MGMP).

From the description above can be concluded that the mastery of learning materials by teachers not in accordance with the expected. This is because the teacher only uses one package book and one student worksheet (LKS) only, and the teacher does not have good teaching preparation as teachers only rely on the lesson plan (RPP) of the subject teachers (MGMP) course, learning materials. The lesson plan (RPP) is only a formality when I ask for a draft of the implementation of the lesson they can not see the lesson plan (RPP) at that time. They can only promise in the next week and next week they can not show the design of the implementation of learning.

\section{2) Learning methods}

Learning methods contain substantive elements or curricular programs, methods of presenting materials, and educational media. A teacher must be able to use methods that will be used in conveying learning materials, in order to achieve maximum educational goals.

The learning method is a way to convey learning materials to students so that the material presented is easily understood and understood. In teaching and learning activities learning method is needed by a teacher in delivering learning materials and teachers are required to be able to use learning methods that vary according to student circumstances.

In the implementation of learning in the classroom, without using learning methods in accordance with the needs of students, the learning objectives will not be achieved in accordance with the expected. Therefore a professional teacher is required to be able to recognize various kinds of learning methods and can apply the methods of learning in the classroom.

A teacher should use the method of conveying learning in the classroom, this is because with the method used in delivering learning materials can help the teacher in explaining the material given to the students. The method used here is a method used by teachers to facilitate the digestion of the learning given to the students.

Based on interviews with history teachers who are educational backgrounds Arkelogi known that the methods used in the implementation of learning history in the class can be said to be quite voracious. Thus it can be said that the history teacher does not use only one method in the learning process. Teachers try to be able to use methods that match the material to be conveyed to the students. This can help teachers to deliver learning materials to students, so students are easier to understand the material described by the teacher. Methods used here such as: a) method of discussion, b) Questioning method, c) lecture method, d) assignment.

The methods employed by the teacher, all adapted to such considerations, look at the breadth of the material, time allocation and so on. The teacher should be able to predict with as much material as it is appropriate to use what method. Therefore, teachers are really required to be able to allocate time well so that teachers do not choose the right method to deliver the material. So with the accuracy in choosing the method to deliver the material, in the end, the learning objectives will be achieved optimally. Therefore the role of methods in teaching and learning process is needed, without using the method in teaching and learning process of learning objectives will not be reached maximally.

Based on the above description can be concluded that the learning method used is lecture method, discussion, and question and answer. From the results of the interview, the teacher has not used a variety of learning methods in accordance with the needs of students to achieve learning objectives. Because the method of learning used is still dominated by the lecture method.

\section{3) Instructional Media}

Learning media has been known for a long time since formal education or teaching exists. There is a lot of understanding or definition of media. But the definitions that appear to have almost the same meaning. Etymologically, the word "media" is the plural of the medium, which in Latin means, means, and intermediaries.

Learning media is a very important tool in the implementation of teaching and learning process because with the learning media presented material becomes more easily understood by students than without using media. Therefore, teachers are required to be creative in making learning media and using learning media. Learning media is very helpful for students to understand the material described by the teacher. In other words, the media is a component of a learning resource or physical vehicle containing instructional materials in a student environment that can stimulate them to learn.

Learning media is needed in teaching and learning process. The use of media in the implementation of education has several benefits. In relation to that Hamalik in [2] suggests the benefits of educational media as follows: a) laying concrete foundations for thinking. B) enlarge students' attention. C) laying the foundations essential for learning development. D) provide real experiences that can foster self-employment activities among students. E) cultivate regular and continuous thinking, especially through live images. G) to help the growth of understanding that can help the development of language skills. H) provide experiences that are not easily obtained by other means, and help more efficiency and diversity in learning.

In the process of teaching and learning, teachers must be creative in creating or creating their own learning media and using learning media that varies according to the needs of 
students so that teaching-learning process will run well and students more easily understand what the teacher explained.

Based on interviews with history teachers with archeology background, it is known that the use of learning media, in general, has not used the media maximally, it is again constrained by the short time allocation for history lessons. However, gradually I tried to use learning media such as using image media, VCD, OHP, laptop. Sometimes constrained technicians like power outages, therefore I get around by using print media like a book package so that my students love to learn history. With a good learning media that can support student achievement, this is due to the learning media students feel or become interested in learning history and does not make students become bored and tired of learning. In addition, the role of instructional media is very important because the learning media can make it easier for students to understand and understand the subject matter described by the teacher. For example, when teaching about the empire at least teachers must use the media images that can arouse the spirit and interest of students to follow the lesson. Here the teacher can use the media images such as images of kings, using a map or globe as a pointer area or region castle. So that the process of teaching and learning becomes fun by students, of course, learning objectives will be achieved in accordance with what we want.

Based on the above explanation it can be concluded that the teacher has not used the learning media during the implementation of teaching and learning process. In terms of learning media is very important in the process of teaching and learning, because with the media learning can attract attention and interest in learning of the students so that the learning process becomes meaningful. In addition, with the learning media students do not feel bored and saturated during the learning process takes place. So that learning objectives will be achieved in accordance with the expected by the teacher.

\section{B. Evaluation}

This component serves to assess the extent to which students' success during learning. Evaluation is very important to assess whether the learning process is going well or not. Evaluation results can provide advice to teachers to improve implementation of the upcoming teaching and learning process.
Evaluation is generally done at the end of the teaching and learning process, such as daily tests, midterms, and semester exams. In the implementation of the evaluation is also done by the teacher during the learning process took place in the classroom and the behavior of students in the school environment.

Based on interviews with history teachers with archeology background, assessment is done by written test, assignment, and student behavior. A) test in writing that is the problem used in the form of objective and essay choice. However, students prefer objective questions, because they are considered easier than essays. For teachers about essays, it is necessary to help students who get low grades of objective matters. B) assignment, ie the teacher gives the task of the home in the form of doing the questions given by the teacher, reading the material for the next week, and others. C) behavior, in which the teacher also sees the students' activeness in the class during the learning and the teacher also assesses the attitude of the students outside the classroom.

From the above description can be concluded that the evaluation conducted by the teacher has not been done maximally because the assessors made more look at the results of daily tests, mid-semester exam, and semester exam only. While in the evaluation of learning there is evaluation process and product evaluation. Evaluation of the process in question is the teacher to observe directly in the classroom to the activities - activities of students during the learning process takes place and evaluation of the product of the teacher ie assigning tasks to students such as making mini reports or making papers.

\section{CONCLUSION}

The result of the research shows that the implementation of learning history at SMA Saraswati 1 Denpasar when viewed from the preparation, implementation, method, media, to evaluation, it can be said that teachers outside of history education qualification is better than a qualified teacher of history education.

\section{REFERENCES}

[1] Zamroni, Pendidikan untuk demokrasi tantangan menuju civil society, Yogyakarta: Bigraf Publishing, 2001.

[2] Arsyad and Lincolin, Ekonomi mikro, Yogyakarta: BPFE, 1996. 